\title{
Infection Risk and Critical Period for the Postharvest Control of Gray Mold (Botrytis cinerea) on Blueberry in Chile
}

\author{
S. A. Rivera, J. P. Zoffoli, and B. A. Latorre, Facultad de Agronomía e Ingeniería Forestal, Pontificia Universidad Católica de Chile,
} Casilla 306-22, Santiago, Chile

\begin{abstract}
Rivera, S. A., Zoffoli, J. P., and Latorre, B. A. 2013. Infection risk and critical period for the postharvest control of gray mold (Botrytis cinerea) on blueberry in Chile. Plant Dis. 97:1069-1074.

Gray mold (Botrytis cinerea) is a major disease of blueberries (Vaccinium spp.), which require more than 15 days of shipment at $0^{\circ} \mathrm{C}$ to reach international markets. The aims of this study were (i) to determine the relative susceptibility of the flowering and fruiting stages, (ii) to determine the critical blueberry growth stages for postharvest gray mold control, and (iii) to determine the infection risks on the basis of weather conditions. The epiphytic colonization of $B$. cinerea of flowers and fruits was demonstrated in blueberry 'Brigitta' and 'Duke' in Antuco and Virquenco. In inoculated flowers and fruits in humid chambers at $20^{\circ} \mathrm{C}$, full bloom and mature fruit stages were the most sus-

ceptible stages. Fungicide applications at the mature fruit stage appeared as the most critical period for gray mold control in stored fruits. The algorithm proposed, which was based on $>6 \mathrm{~h}$ of wetness between 14 and $25^{\circ} \mathrm{C}$, allowed the estimation of the periods of $\mathrm{B}$. $\mathrm{Ci}$ nerea infection risk. A significant correlation between the $B$. cinerea infection risk and gray mold incidence in stored fruits was obtained $(r=0.96, P<0.0001)$. Therefore, this algorithm has the potential to optimize fungicide applications under field conditions, but field validation of this algorithm remains to be determined.
\end{abstract}

Highbush blueberry (Vaccinium spp.) is a high-value export crop cultivated on over 8,400 ha across a range of diverse soil conditions and climate zones in Chile (www.odepa.cl). The commercial plantings in Chile extend from latitude $29^{\circ}$ to $42^{\circ}$ south, with harvesting from October to April (1). The blueberries are exported mainly to the United States (3), but markets in Europe and Asia are increasing. Blueberry flowers and fruits can be affected by several fungal diseases $(5,16,23,24)$, with the gray mold caused by Botrytis cinerea Pers. ex Fr. (teleomorph Botryotinia fuckeliana (de Bary) Whetzel) being one of the most frequent and severe diseases.

Gray mold commonly occurs in blueberry plantings in Chile (31) when favorable weather conditions prevail during the growing season and causes blossom and twig blights and a soft decay in mature fruits at harvest time and during storage $(2,5,29,30,32)$. Furthermore, although the blueberries are transported at near $0^{\circ} \mathrm{C}$, the Chilean blueberry transport to market requires more than 15 days by sea, with severe losses often occurring (3).

As proposed for other fruit crops $(10,13,18,21)$, it is postulated that the postharvest gray mold decay of blueberry can be initiated at flowering or during the early stages of fruit development, remaining latent until harvest and postharvest. Therefore, to prevent severe losses due to gray mold during storage and transportation, fungicide treatments have been proposed between flowering and fruit maturity, and several fungicides have been registered in Chile, including anilinopyrimidines (e.g., cyprodinil) and anhydroxanilide (e.g., fenhexamid) (www.sag.gob.cl). Recently, sulfur dioxide $\left(\mathrm{SO}_{2}\right)$ treatments applied to packed fruits just after harvest have been advocated to prevent gray mold decay during storage and transportation $(8,27)$.

However, further studies are needed to establish the critical growth stages for gray mold control in the current blueberry cultivars planted at a relatively high density in Chile. This information would be valuable for the timing of fungicide treatments. Although

Corresponding author: B. A. Latorre, E-mail: blatorre@uc.cl

Accepted for publication 14 February 2013.

http://dx.doi.org/10.1094/PDIS-12-12-1112-RE

(C) 2013 The American Phytopathological Society such weather conditions as the temperature and duration of free moisture have been previously related to $B$. cinerea infection in table grapes $(6,20)$ and strawberries $(7)$, the effect of such factors has yet to be studied with regard to gray mold in blueberries. Therefore, this study was conducted (i) to determine the relative susceptibility of the flowering and fruiting stages to B. cinerea, (ii) to determine the critical blueberry growth stages for postharvest gray mold control, and (iii) to determine the infection risks on the basis of weather conditions.

\section{Materials and Methods}

B. cinerea identification. To verify the symptoms of $B$. cinerea infection in blueberry flowers and fruits, brown necrotic petals $(n=$ 10 per replicate) and decayed fruits $(n=10$ per replicate) were placed in potato dextrose agar acidified with $0.5 \mathrm{ml} 96 \%$ lactic acid per liter (APDA). Colonies of $B$. cinerea were identified on the basis of the morphology of their conidia and conidiophores and the presence of sclerotia on APDA.

$B$. cinerea in apparently healthy flowers and fruits. Apparently healthy flowers and fruits of blueberry 'Brigitta' (late season harvest) and 'Duke' (early midseason harvest) were randomly obtained in 2011 from two commercial plantings, Antuco $\left(37^{\circ} 26^{\prime} \mathrm{S}\right.$, $\left.72^{\circ} 14^{\prime} \mathrm{W}\right)$ and Virquenco $\left(37^{\circ} 28^{\prime} \mathrm{S}, 72^{\circ} 31^{\prime} \mathrm{W}\right)$. Flower samples were collected randomly at the stages of late pink bud, full bloom, and petal fall. Fruits were randomly sampled at the stages of late green fruit (total soluble solids [TSS]: 5.4 to $6.5 \%$ ), fruit coloring (TSS: 6.9 to $7.6 \%$ ), first blue fruit (TSS: 8.7 to $11.7 \%$ ), mature fruits (TSS: 11.5 to $13.6 \%$ ), and over-mature fruits (TSS: 13.6 to $15.7 \%$ ). The flower and fruit samples were transported to the laboratory in an ice chest, and 200 flowers or 200 fruits per each growth stage were selected. The TSS was determined using a digital refractometer (model PR-101, Atago Co., Tokyo, Japan). The titratable acidity (expressed as citric acid equivalents) was determined for each fruit sample $(5 \mathrm{ml}$ of blueberry fruit juice plus 35 $\mathrm{ml}$ of distilled water) by titrating the juice solution with $0.1 \mathrm{~mol}$ liter ${ }^{-1} \mathrm{NaOH}$ to $\mathrm{pH}$ 8.2.

To determine the presence of $B$. cinerea, flower and fruit samples were placed in humidity chambers $(100 \%$ relative humidity $[\mathrm{RH}]$ ) for 6 days at $20^{\circ} \mathrm{C}$, and the proportion of flowers and fruits showing gray mold symptoms and signs was determined. In addition, $10 \mathrm{~g}$ of flowers collected at the full bloom stage were washed 
with $30 \mathrm{ml}$ sterile $0.05 \%$ Tween 80 and manually agitated for $60 \mathrm{~s}$. An aliquot $(20 \mu \mathrm{l})$ of the resulting suspension was plated on a 90 $\mathrm{mm}$ petri plate containing APDA plus $0.05 \mathrm{~g}$ tetracycline (SigmaAldrich, AT), $0.1 \mathrm{~g}$ streptomycin (Sigma-Aldrich, AT), and $1 \mathrm{ml}$ Igepal CO-630 (Sigma-Aldrich, AT) as a colony restrictor (APDAm). The plates were incubated at $20^{\circ} \mathrm{C}$ for 7 days prior to the determination of the total number of $B$. cinerea colonies under a stereoscopic microscope. Samples (50 g) collected at the late green fruit stage were washed with $50 \mathrm{ml}$ of sterile Tween 80 and agitated for $60 \mathrm{~s}$; colony isolation was performed as indicated above for the flower samples. The results were expressed as colony forming units (CFU) per gram of flowers or fruits.

Relative susceptibility of flowers and fruits to $B$. cinerea. To study the relative susceptibility of the flowering and fruiting stages, flowers and fruits were sampled in commercial Brigitta and Duke blueberry plantings at the growth stages described above. The flower and fruit samples were distributed in humidity chambers before spraying them with $100 \mu \mathrm{l}$ conidial suspension $\left(10^{5}\right.$ conidia per $\mathrm{ml}$ ) of $B$. cinerea (isolate BCA1); the conidia were obtained from 7- to 14-day-old cultures on APDA. The flower and fruit samples were incubated for 6 days at $20^{\circ} \mathrm{C}$ and then assessed for gray mold prevalence. An equal number of flowers and fruits treated with sterile water were used as naturally infected flowers and fruits. This experiment was repeated once.

Critical period for fungicide treatments. The effect of the timing of preharvest fungicide treatment on the postharvest gray mold prevalence was studied in blueberry cultivars Brigitta and Duke sprayed at one of the following growth stages: (i) late pink bud, (ii) full bloom, (iii) fruit coloring (TSS: 6.9 to $7.6 \%$ ), (iv) first blue fruits (TSS: 8.7 to $11.7 \%$ ), and (v) mature fruits (TSS: 11.5 to $15.0 \%$ ). Fungicide applications were performed with $0.5 \mathrm{~g} \mathrm{liter}^{-1}$ fenhexamid (Teldor 500SC, Bayer CropScience S.A., Chile) applied at 4.14 bar until runoff with a manual backpack sprayer (model 425, SOLO, Sindelfingen, Germany) using $375 \mathrm{ml}$ per plant. For comparison, mature fruits harvested from untreated plants were fumigated with a $300\left(\mu l\right.$ liter $\left.^{-1}\right) \mathrm{h} \mathrm{SO}_{2}$ concentration time $(\mathrm{C} t)$ product at 20 to $22^{\circ} \mathrm{C}$ in $30.5 \mathrm{~m}^{3}$ (30,500 liter) steel chambers (27). This experiment was conducted at a high-density commercial planting (3,333 plants per ha) located in Antuco and was repeated using the same blueberry cultivars in Virquenco.

To evaluate the effect of fungicide timing on the postharvest gray mold prevalence, approximately $150 \mathrm{~g}$ of fruits per plant, from each treatment, were harvested at commercial maturity (TSS: 11.5 to $16.5 \%), 3$ days after the last fungicide application. The pedicels were removed, and the fruits ( $125 \mathrm{~g}$ ) were packed in polyethylene terephthalate (PET) clamshells. All the fruits were placed in polyethylene bags $(\mathrm{RH}>90 \%)$ and stored for 45 days at $0.0 \pm$ $0.5^{\circ} \mathrm{C}$ to simulate the maritime transportation to markets and for 3 days at $20.0 \pm 1.0^{\circ} \mathrm{C}$ to simulate the commercialization period prior to the assessment of the gray mold prevalence. The relative humidity and temperature were determined using a Hobo Pro RH/Temperature data logger (Onset Computer Co., MA).

To corroborate the results obtained in the first year, this study was repeated in two plantings (Osorno $\left[40^{\circ} 37^{\prime} \mathrm{S}, 72^{\circ} 54^{\prime} \mathrm{W}\right.$ ] and San Pablo $\left[40^{\circ} 34^{\prime} \mathrm{S}, 73^{\circ} 03^{\prime} \mathrm{W}\right]$ ) of blueberry 'Aurora' and in one planting of blueberry 'Liberty' in Osorno during 2012; the blueberry plants were treated with $0.5 \mathrm{~g} \mathrm{liter}^{-1}$ fenhexamid only at the mature fruit stage (TSS: 10.5 to $12.9 \%$ ) at 5 days before harvest. The fruits were harvested and packed without the pedicel in $125 \mathrm{~g}$ PET clamshells prior to fumigation with $300\left(\mu \mathrm{l}\right.$ liter $\left.^{-1}\right) \mathrm{h} \mathrm{SO}_{2} \mathrm{Ct}$ product, as indicated above. The fruits were stored in polyethylene bags for 45 days at $0.0 \pm 0.5^{\circ} \mathrm{C}$ and for 3 days at $20^{\circ} \mathrm{C}$ prior to the evaluation of gray mold incidence. An equal number of untreated fruits were used as the control.

Infection risk based on weather conditions. To characterize the weather conditions favorable for gray mold infection, a microweather station provided with temperature and leaf wetness (LW) sensors was installed at $1.5 \mathrm{~m}$ height in four blueberry plantings in

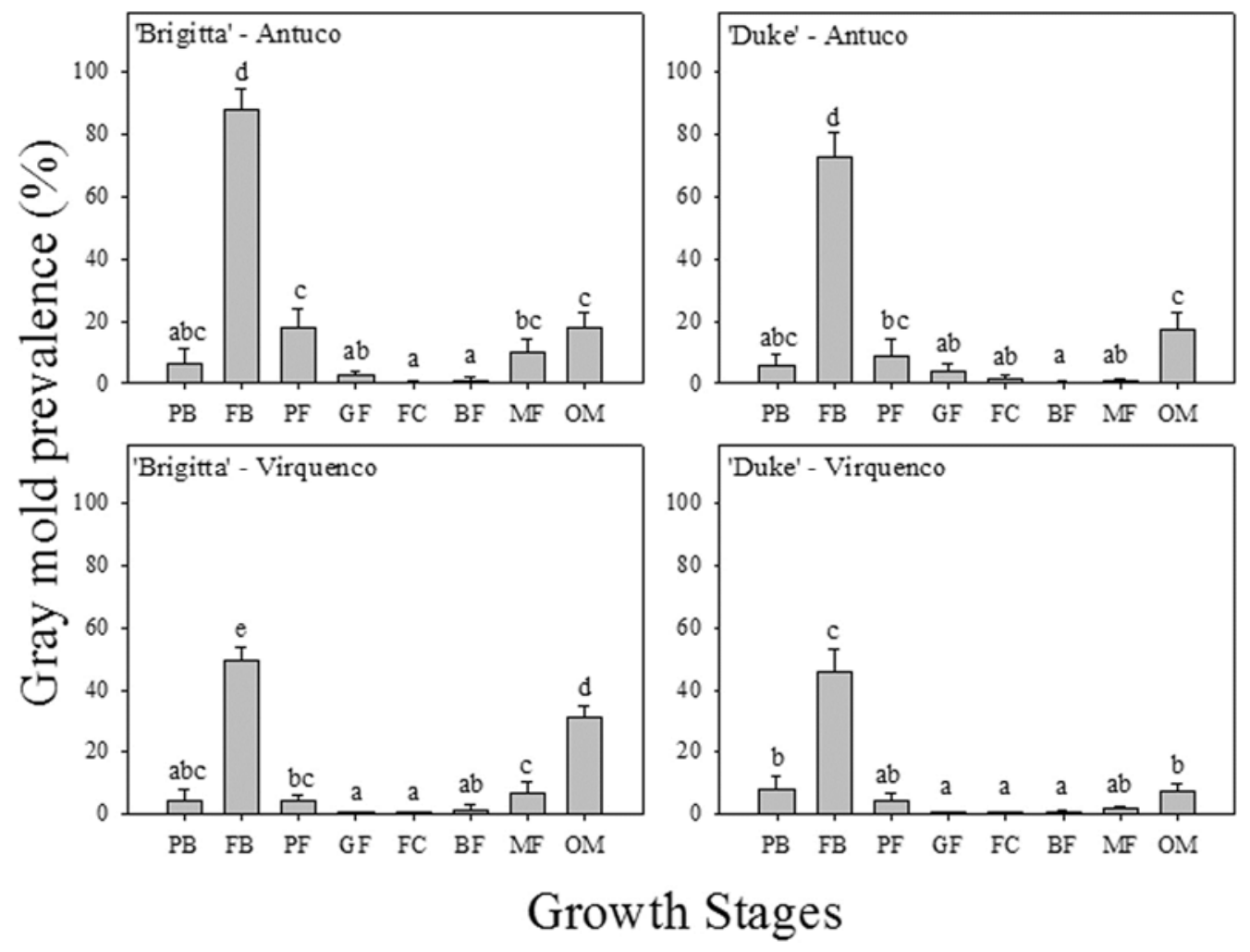

Fig. 1. Detection of Botrytis cinerea in apparently healthy flowers and fruits at different stages of blueberry development, as estimated by the gray mold prevalence obtained in flower and fruit samples incubated for 6 days at $20^{\circ} \mathrm{C}$ in humid chambers $(100 \% \mathrm{RH}) . \mathrm{PB}=$ late pink bud, $\mathrm{FB}=$ full bloom, $\mathrm{PF}=$ petal fall, $\mathrm{GF}=\mathrm{green}$ fruits of 8.1 to $8.8 \mathrm{~mm}$ diameter, $\mathrm{FC}=$ fruit coloring (green to pink fruits), $\mathrm{BF}=$ first blue fruits $(<25 \%$ dark blue fruits), $\mathrm{MF}=$ mature fruits, and OM = over-mature fruits. Means followed by the same letter were not significantly different according to Fisher's LSD $(P=0.05)$. Percentages were transformed to the arcsine sqrt $(x)$ prior to analysis, but the untransformed data are presented. 
Antuco, San Clemente $\left(35^{\circ} 30^{\prime} \mathrm{S}, 71^{\circ} 30^{\prime} \mathrm{W}\right)$, Yerbas Buenas $\left(35^{\circ} 41^{\prime} \mathrm{S}, 71^{\circ} 30^{\prime} \mathrm{W}\right)$, and Virquenco. The temperature was recorded using an EHT sensor (Decagon Devices Inc., WA), and the free moisture duration was recorded using a dielectric leaf wetness sensor (Decagon Devices Inc.). The temperature sensor and LW sensor were connected to a five-channel data logger (model Em50, Decagon Devices Inc.), recording every $10 \mathrm{~min}$.

An algorithm to estimate the risk of gray mold infection was based on previous information of the temperature and free moisture requirements for table grape infection (20). The risk of an infection period was initiated if rain, dew, or fog occurred and the air temperature was between 14 and $25^{\circ} \mathrm{C}$. Based on this information, the infection risk was classified as low, moderate, or high when the moisture periods were 6 to $11 \mathrm{~h}, 12$ to $15 \mathrm{~h}$, and $\geq 16 \mathrm{~h}$, respectively. Therefore, a threshold of $6 \mathrm{~h}$ of moisture was considered sufficient for infection. The moisture periods were summed if the moisture conditions were interrupted for $\leq 4 \mathrm{~h}$.

The weather conditions favorable for gray mold infection were correlated with the proportion of gray mold obtained on stored blueberries Brigitta, Duke, and Liberty. A 125-g sample of untreated mature fruits were randomly harvested for each of 5 replicates and stored, as indicated above, for 45 days at $0^{\circ} \mathrm{C}$ plus 3 days at $20^{\circ} \mathrm{C}$ at $\mathrm{RH}>90 \%$. The estimation of infection risks started at tight cluster stage and ended at harvest. The total numbers of infection risk periods were correlated with the proportion of fruits infected with gray mold.

Experimental design and statistical analysis. For the effect of growth stages and relative susceptibility of flowers and fruits to $B$. cinerea, treatments were distributed as a completely random design with four replicates of 50 flowers or 50 fruits each. An analysis of variance was performed, and the means were separated according to Fisher's least significant difference (LSD) $(P=0.05)$. The relationship between TSS and gray mold prevalence obtained for the inoculated detached fruits, and titratable acidity and gray mold prevalence obtained for the inoculated detached fruits was evalu- ated using a linear Pearson correlation model. The gray mold prevalence $(y)$ was $\log 10(y+1)$ transformed prior to the analysis.

To study the effect of preharvest fungicide applications on postharvest gray mold prevalence, the fungicide treatments were arranged as a completely randomized block design, with five replicates of one plant as the experimental unit, leaving two plants on each side to avoid contamination among adjacent treatments. Gray mold prevalence was estimated using a random sample of $125-\mathrm{g}$ fruits per plant. Means were separated according to Fisher's LSD $(P=0.05)$.

The relationship between weather conditions (number of infection risk periods) and proportion of fruits affected by gray mold were determined by Pearson correlation using the data obtained in the four commercial blueberry plantings.

The analyses were performed with the statistical software SigmaStat (Systat Software Inc., San José, CA).

Percent values were transformed to arcsine sqrt $(x)$ prior to statistical analysis; however, the nontransformed values are presented.

\section{Results}

B. cinerea identification. $B$. cinerea was consistently isolated from necrotic petals and decayed fruits. The colonies were initially white and turned light brown after 7 to 10 days on APDA. Abundant, free-branched conidiophores formed nonseptated ellipsoidal to ovoid hyaline conidia of (8.7)11.6 $\pm 1.6(14.9) \times(6.2) 7.5 \pm$ $0.8(9.1) \mu \mathrm{m}$. Sclerotia of variable sizes and forms were produced on APDA

B. cinerea in apparently healthy flowers and fruits. Independently of the geographical location, gray mold was induced in 0.0 to $88.1 \%$ and 0.5 to $72.5 \%$ of the apparently healthy samples of blueberry flowers of cultivars Brigitta and Duke, respectively. Blueberry growth stages had a significant effect $(P<0.05)$ on gray mold prevalence, with the highest prevalence at full bloom and the lowest prevalence obtained both at the fruit coloring and first blue fruit stages (Fig. 1).
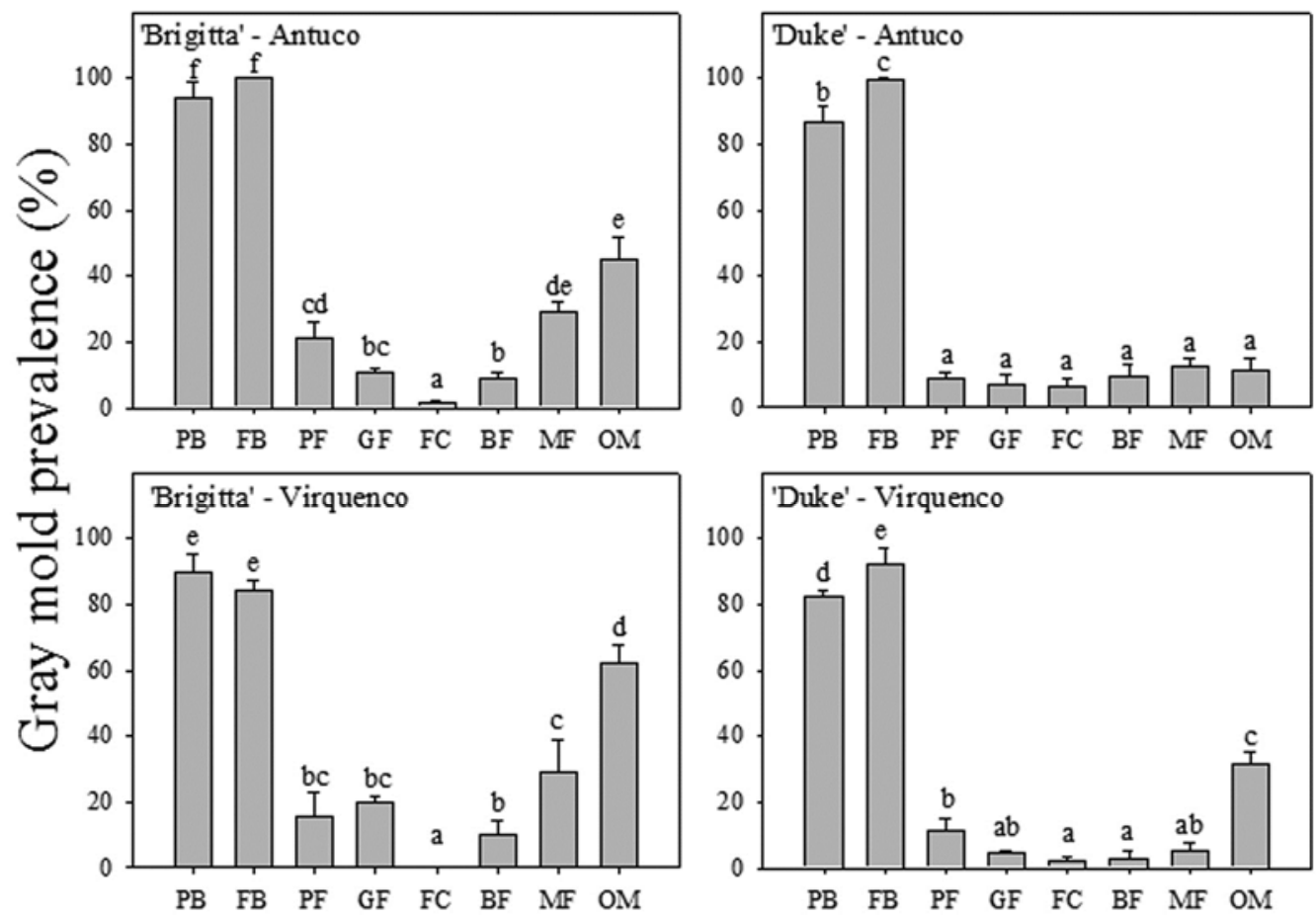

\section{Growth stages}

Fig. 2. Relative susceptibility of blueberry flowers and fruits to Botrytis cinerea, as determined using inoculated flower and fruit samples after 6 days at $20^{\circ} \mathrm{C}$ in humid chambers $(100 \% \mathrm{RH})$. $\mathrm{PB}=$ late pink bud, $\mathrm{FB}=$ full bloom, $\mathrm{PF}=$ petal fall, $\mathrm{GF}=$ green fruits of 8.1 to $8.8 \mathrm{~mm}$ diameter, $\mathrm{FC}=$ fruit coloring (green to pink fruits), BF = first blue fruits $(<25 \%$ dark blue fruits), MF = mature fruits, and $\mathrm{OM}=$ over mature fruits. Means followed by the same letter (columns) were not significantly different according to Fisher's LSD $(P=0.05)$. Percentages were transformed to the arcsine sqrt $(x)$ prior to analysis, but the untransformed data are presented. 
B. cinerea was detected (6 to $375 \mathrm{CFU} / \mathrm{g}$ of fruit) in the suspensions obtained after washing apparently healthy fruits at the stage of late green fruits, whereas $B$. cinerea was nondetectable in apparently healthy samples of flowers collected at full bloom.

Relative susceptibility of flowers and fruits to $B$. cinerea. For inoculated blueberry flowers and fruits, gray mold prevalence varied from 0.0 to $100 \%$ and from 2.0 to $99.5 \%$ for Brigitta and Duke, respectively. The relative susceptibility varied significantly $(P<$ 0.05 ) among the flower growth stages and fruit growth stages, with late pink bud and full bloom being the most susceptible flower stages and over-mature fruit appearing to be a highly susceptible fruit stage (Fig. 2). The least susceptible fruit growth stage $(P<$ 0.05 ) was the period between fruit coloring and the first blue fruits. Regardless of the blueberry cultivar and geographical location, gray mold prevalence consistently increased from the fruit coloring to over-mature fruit stages (Fig. 2).
A linear model best explained the relationship between the TSS concentration $(x)$ and gray mold prevalence $(y)(\log 10(y+1)=$ $\left.-0.41+0.12 x, R^{2}=0.59, P<0.0005\right)$, with a positive Pearson correlation coefficient ( $r=0.77, P<0.0005$ ). Additionally, a linear model best explained the relationship between the titratable acidity $(x)$ and gray mold prevalence $(y)\left(\log 10(y+1)=1.5-0.63 x, R^{2}=\right.$ $0.73, P<0.0001)$, with a negative Pearson correlation coefficient $(r=-0.84, P<0.0001)$ using the data obtained between the fruit coloring and over mature fruit stages.

Critical period for fungicide treatments. The timing of fungicide application had a significant $(P<0.05)$ effect on postharvest gray mold prevalence. The highest gray mold prevalence in the stored fruits was obtained when the blueberry plants were only treated with fenhexamid at the late pink bud stage (PB), developing 18.0 to $22.8 \%$ and 1.4 to $9.5 \%$ prevalence for blueberry Brigitta and Duke, respectively (Fig. 3). The prevalence significantly $(P<$
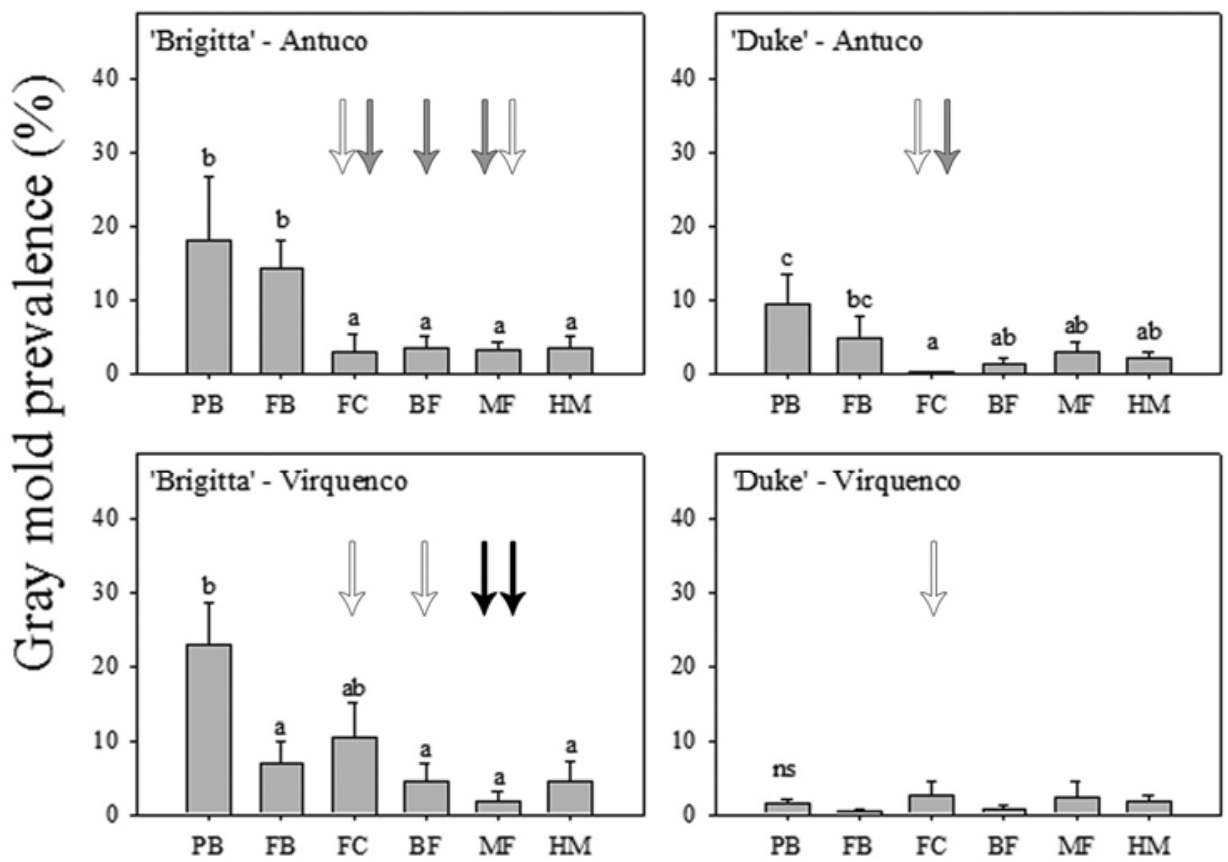

\section{Growth stages}

Fig. 3. Effect of preharvest fungicide applications on postharvest gray mold (Botrytis cinerea) prevalence on blueberry 'Brigitta' and 'Duke' in Antuco and Virquenco. Fruits were stored for 45 days at $0^{\circ} \mathrm{C}$ plus 3 days at $20^{\circ} \mathrm{C}$. $\mathrm{PB}=$ late pink bud, $\mathrm{FB}=$ full bloom, $\mathrm{FC}=$ fruit coloring, $\mathrm{BF}=$ first blue fruits, $\mathrm{MF}=$ mature fruits, and $\mathrm{HM}=$ harvested mature fruits. Field treatments were performed using fenhexamid $\left(0.5 \mathrm{~g} \mathrm{liter}^{-1}\right)$, and the harvested mature fruits $(\mathrm{HM})$ were only fumigated with sulfur dioxide $\left(300\left(\mu \mathrm{l}\right.\right.$ liter $\left.\left.{ }^{-1}\right) \mathrm{h}\right)$. Means followed by the same letters were not statistically significant according to Fisher's $L S D(P \leq 0.05)$. Bars $=$ standard error of mean of five replicates. ns $=$ not significant. Each arrow represents a single infection risk event based on weather conditions: low risk (white arrows), moderate risk (gray arrows), and high risk (black arrows).

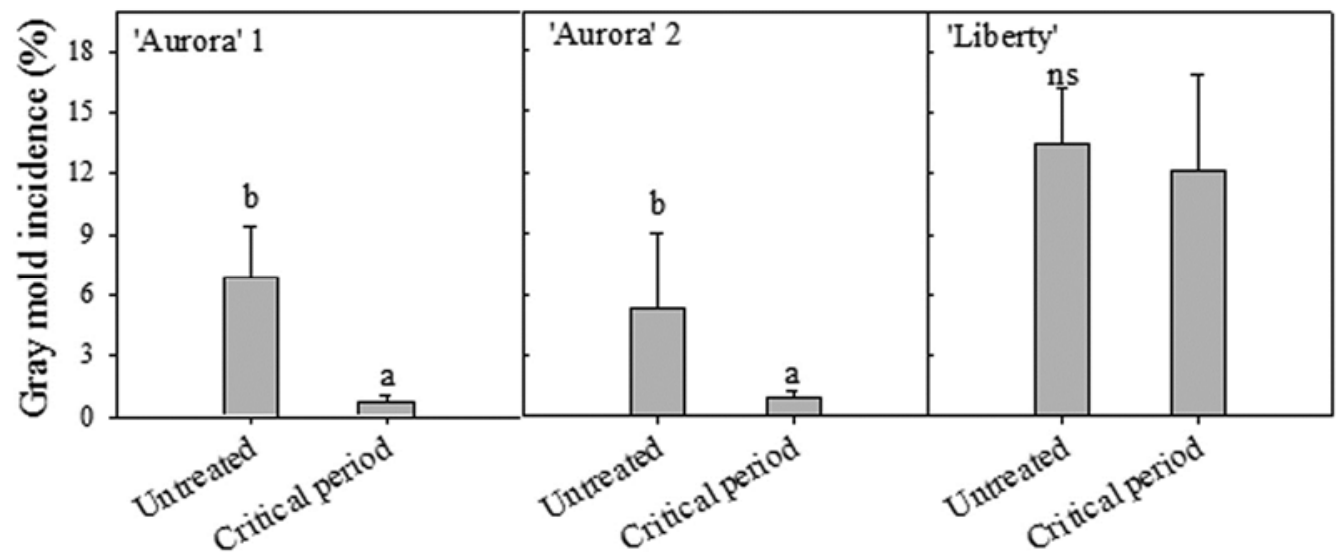

Fig. 4. Effect of one fungicide treatment $\left(0.5 \mathrm{~g} \mathrm{lite}^{-1}\right)$ at the mature fruit stage (critical period) plus sulfur dioxide $\left(300\left(\mu \mathrm{l}\right.\right.$ liter $\left.\left.{ }^{-1}\right) \mathrm{h}\right)$ fumigation at harvest on the incidence of gray mold (Botrytis cinerea) in stored $\left(45\right.$ days at $0^{\circ} \mathrm{C}$ and 3 days at $20^{\circ} \mathrm{C}$ ) blueberries. Means of four replicates followed by the same letters were not statistically significant according to Fisher's LSD $(P \leq 0.05)$. Bars $=$ standard error. ns $=$ not significant. 
0.05 ) decreased to 1.9 to $3.5 \%$ in the stored fruits when the blueberry plants were treated at the mature fruit (MF) stage (Fig. 3). Similarly, gray mold prevalence significantly decreased $(P<0.05)$ when the harvested mature fruits (HM) were treated with $\mathrm{SO}_{2}$ (Fig. 3).

For the three other experiments, a significant protection of blueberry was obtained in two of the three trials using blueberry Aurora treated with fenhexamid at the mature fruit stage, 4 days before harvest, followed by $\mathrm{SO}_{2}$ fumigation just after harvest (Fig. 4).

Infection risk based on weather conditions. Favorable weather conditions for gray mold infection were observed in the four geographical locations analyzed. The total number of infection risk periods varied among geographical locations, from one in Yerbas Buenas to five in Antuco (Table 1). Similarly, infection risk level varied with geographical location, from low in San Clemente and Yerbas Buenas to high in Virquenco where two high infection risk events were determined at the mature fruit stage (MF) for blueberry Brigitta. In Antuco, moderate infection risks were determined at the fruit stages of fruit coloring (FC), first blue fruits (BF), and mature fruit (MF) for Brigitta (Fig. 3, Table 1). A linear regression between $x=$ number of infection risk periods and $y=$ proportion of fruits affected by gray mold was obtained $(y=0.011+0.044 x ; r=$ 0.96, $P<0.0001$ ) (Fig. 5).

\section{Discussion}

Gray mold caused by $B$. cinerea is considered to be a major disease of blueberry in Chile $(4,31)$. The results of the present study reinforced the importance of this fungus in stored blueberries as the main concern of farmers during commercialization $(12,27)$. In

Table 1. Risk periods favorable to Botrytis cinerea infection based on the weather conditions in four blueberry plantings in southern Chile

\begin{tabular}{|c|c|c|c|}
\hline Date & $\begin{array}{c}\text { Mean air } \\
\text { temperature }{ }^{\mathrm{a}}\left({ }^{\circ} \mathrm{C}\right)\end{array}$ & $\begin{array}{c}\text { Free moisture }^{\text {b }} \\
\text { (h) }\end{array}$ & $\begin{array}{c}\text { Infection risk } \\
\text { level }^{\mathbf{c}}\end{array}$ \\
\hline \multicolumn{4}{|c|}{ Antuco $\left(37^{\circ} 26^{\prime} \mathrm{S}, 72^{\circ} 14^{\prime} \mathrm{W}\right)$} \\
\hline 19 Nov & 14.6 & 8 & Low \\
\hline $21 \mathrm{Nov}$ & 16.1 & 12 & Moderate \\
\hline $29 \mathrm{Dec}$ & 17.9 & 13 & Moderate \\
\hline 01 Jan & 14.5 & 12 & Moderate \\
\hline 04 Jan & 15.1 & 9 & Low \\
\hline Cultivar & Risk, no. & \multicolumn{2}{|c|}{ Mean prevalence $(\%)^{\mathrm{d}}$} \\
\hline Brigitta & 5 & \multicolumn{2}{|c|}{24.8} \\
\hline Duke & 2 & \multicolumn{2}{|l|}{10.8} \\
\hline Liberty & 5 & \multicolumn{2}{|l|}{20.3} \\
\hline \multicolumn{4}{|c|}{ San Clemente $\left(35^{\circ} 30^{\prime} \mathrm{S}, 71^{\circ} 30^{\prime} \mathrm{W}\right)$} \\
\hline $25 \mathrm{Sep}$ & 16.2 & 6 & Low \\
\hline $23 \mathrm{Dec}$ & 15.2 & 6 & Low \\
\hline $07 \mathrm{Jan}$ & 15.1 & 6 & Low \\
\hline Cultivar & Risk, no. & \multicolumn{2}{|c|}{ Mean prevalence $(\%)^{\mathrm{d}}$} \\
\hline Duke & 1 & \multicolumn{2}{|l|}{7.4} \\
\hline Liberty & 3 & \\
\hline \multicolumn{4}{|c|}{ Virquenco $\left(37^{\circ} 28^{\prime} \mathrm{S}, 72^{\circ} 31^{\prime} \mathrm{W}\right)$} \\
\hline 19 Nov & 14.5 & 8 & Low \\
\hline $02 \mathrm{Dec}$ & 16.3 & 8 & Low \\
\hline $29 \mathrm{Dec}$ & 17.8 & 16 & High \\
\hline $01 \mathrm{Jan}$ & 16.3 & 18 & High \\
\hline $04 \mathrm{Jan}$ & 15.9 & 12 & Moderate \\
\hline Cultivar & Risk, no. & \multicolumn{2}{|c|}{ Mean prevalence $(\%)^{\mathrm{d}}$} \\
\hline Brigitta & 4 & \multicolumn{2}{|c|}{17.6} \\
\hline Duke & 1 & \multicolumn{2}{|l|}{2.3} \\
\hline \multicolumn{4}{|c|}{ Yerbas Buenas $\left(35^{\circ} 41^{\prime} \mathrm{S}, 71^{\circ} 30^{\prime} \mathrm{W}\right)$} \\
\hline 27 Oct & 15.6 & 7 & Low \\
\hline Cultivar & Risk, no. & \multicolumn{2}{|c|}{ Mean prevalence $(\%)^{\mathrm{d}}$} \\
\hline Brigitta & 1 & 5.9 & \\
\hline Duke & 1 & 4.9 & \\
\hline
\end{tabular}

a Mean air temperature during the free moisture period.

${ }^{\mathrm{b}}$ Hours of free moisture when the air temperature ranged from 14 to $25^{\circ} \mathrm{C}$.

${ }^{\mathrm{c}}$ Low infection risk is defined as free moisture periods of 6 to $12 \mathrm{~h}$, moderate infection risk is defined as free moisture period between 12 and 16 $\mathrm{h}$, and high infection risk is defined as a free moisture period $>16 \mathrm{~h}$.

${ }^{\mathrm{d}}$ Gray mold prevalence was determined in 200 nontreated mature fruits after 45 days at $0^{\circ} \mathrm{C}$ plus 3 days at $20^{\circ} \mathrm{C}$ and $\mathrm{RH}>90 \%$. the present study, B. cinerea was identified on gray moldinfected tissues, and gray mold was successfully induced in flower and fruit samples under laboratory conditions using conidia of B. cinerea.

The results of the current study suggest that $B$. cinerea is a component of the epiphytic mycoflora on apparently healthy blueberry flowers and fruits and can serve as an inoculum source for fruit infections. Furthermore, B. cinerea was detected in a suspension obtained from washing blueberry fruit, as has been demonstrated for other hosts using similar methodologies $(11,17,19)$. However, $B$. cinerea was not detected in a suspension obtained from blueberry flowers that can be attributed to the low sensitivity of this test. Additionally, a recent report using a quantitative real-time PCR (qPCR) detection method has demonstrated the presence of latent $B$. cinerea infection in grape berries (28). Therefore, the incubation of flowers and fruits in humid chambers at $20^{\circ} \mathrm{C}$ for 6 days appears to be a useful methodology to estimate the proportion of flowers and fruits naturally contaminated with $B$. cinerea under field conditions.

Previously, it has been suggested that the blossom and fruit maturity stages are the most gray mold susceptible growth stages of northern highbush blueberry 'Bluejay' (4). The results of the present study conducted on northern blueberry cultivars Brigitta and Duke also indicated that the full bloom stage and mature fruit stage were the most susceptible growth stages of blueberry to $B$. cinerea. However, differences in susceptibility to infection may occur considering that detached flowers and fruits were used in this study. An increase in $B$. cinerea susceptibility at or near full bloom has also been reported for inoculated potted rabbiteye and southern highbush blueberries (29). In the flowers of other fruit species, the presence and abundance of pollen grains and pollen exudates $(14,22)$ and low levels of resveratrol (18) were related to a high propensity to $B$. cinerea infection during full bloom. Additionally, the susceptibility of blueberry fruits to $B$. cinerea rapidly increased from fruit coloring to over-mature fruits. The drastic change in gray mold susceptibility obtained in this study during fruit ripening can be attributed to a decrease in the phenol, organic acid, and resveratrol contents and an increase in sugar concentration, as has been proposed for other fruits $(9,14,25,26)$. Moreover, the data obtained in the current study demonstrated that gray mold prevalence increased as the TSS content of the blueberry fruits increased. Similarly, gray mold prevalence increased as the blueberry fruits lost acidity.

Nevertheless, the mature fruit stage, rather than the full bloom stage, was the critical period for fungicide application because fenhexamid applied at the mature fruit stage allowed the highest gray mold reduction in stored blueberries. These results were similar to a previous report (19) in which fungicide applied during berry ripening resulted in a more effective control than fungicide

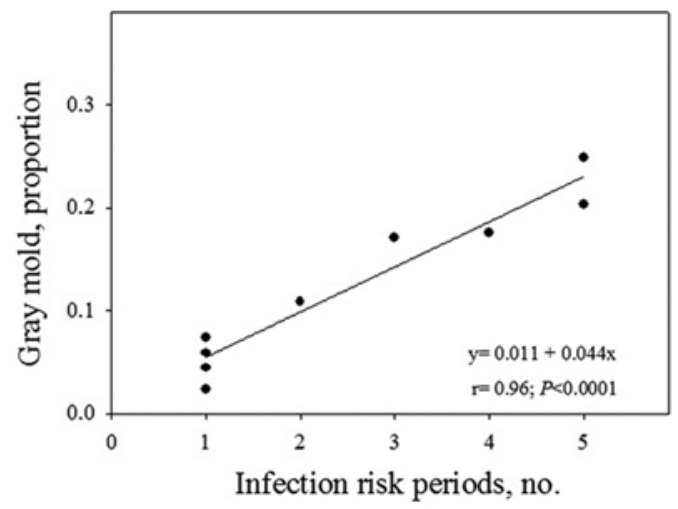

Fig. 5. Relationship between number of infection risk periods in blueberry plantings and proportion of blueberry fruits affected by gray mold (Botrytis cinerea) when stored for 45 days at $0^{\circ} \mathrm{C}$ plus 3 days at $20^{\circ} \mathrm{C}$. Gray mold prevalence was estimated in 125-g fruit samples for each of five replicates obtained from untreated plants. $r=$ Pearson correlation coefficient. 
applications at flowering for reducing postharvest gray mold on table grapes.

The lack of control obtained with the fungicide applications during flowering can be explained by the absence of infection risk during full bloom obtained in the present study. Additionally, it is possible that the infected flowers and young fruits may have abscised, as previously reported in blackcurrant $(13,33)$. These findings suggest that flower infection has little importance on gray mold infection during the storage of blueberry; therefore, fungicide applications should be focused on the stages of mature fruit development.

The algorithm used in this study, which was based on a previous report (20), was an easy and useful tool to estimate the infection risk of gray mold in blueberry fruits. This algorithm revealed temperature and moisture conditions as the main factors triggering gray mold infection in blueberry flowers and fruits, as has been demonstrated previously in blueberry and other fruit crops $(6,7,15,20)$. Based on the present results, the number of infection risk periods was positively correlated $(r=0.96, P<0.0001)$ with gray mold prevalence in stored blueberries, suggesting that this algorithm can be used to predict the weather conditions favorable for gray mold infection in the field. To our knowledge, this is the first attempt to characterize $B$. cinerea infection events in blueberry fruits based on field weather conditions and could permit forecasts for fungicide application for the control of postharvest gray mold, similar to the proposal for fungicide forecast against gray mold on table grapes (6). However, further research is needed before applying this algorithm under commercial conditions.

In the present study, the infection risk periods coincided with both the most efficient periods of fungicide application for gray mold control and the infection risk levels. The application of fenhexamid to Brigitta in Virquenco at the mature fruit stage was performed one day between two high infection risk events and resulted in the smallest gray mold prevalence of all the fungicide treatments.

In conclusion, fungicide applications performed on mature fruit can efficiently protect stored blueberry fruits against gray mold when the infection risk periods were determined on the basis of temperature and free moisture conditions.

\section{Acknowledgments}

This project was partially financed by the Innova-Corfo project 09-IEI-6942 and Fondecyt project 1100246 . The authors are grateful to Hortifrut for providing the fruits that were used in this study.

\section{Literature Cited}

1. Bañados, M. P. 2006. Blueberry production in South America. Acta Hortic. 715:165-172.

2. Barrau, C., de los Santos, B., and Romero, F. 2006. Susceptibility of southern highbush and rabbiteye blueberry cultivars to postharvest diseases in Huelva, Spain. Acta Hortic. 715:525-530.

3. Beaudry, R. M., Moggia, C. E., Retamales, J. B., and Hancock, J. F. 1998. Quality of 'Ivanhoe' and 'Bluecrop' blueberry fruit transported by air and sea from Chile to North America. HortScience 33:313-317.

4. Bensch, E., and Guerrero, J. 2001. Eficacia de benomilo+captan y BC1000 en el control de Botrytis cinerea y Alternaria alternata en arándano alto (Vaccinum corymbosum) cv. Bluejay. Agro Sur 29:12-19.

5. Bristow, P. R., and Milholland, R. D. 1995. Botrytis blight. Pages 8-9 in: Compendium of Blueberry and Cranberry Diseases. F. L. Caruso and D. C. Ramsdell, eds. American Phytopathological Society, St. Paul, MN.

6. Broome, J. C., English, J. T., Marois, J. J., Latorre, B. A., and Aviles, J. C. 1995. Development of an infection model for Botrytis bunch rot of grapes based on wetness duration and temperature. Phytopathology 85:97-102.

7. Bulger, M. A., Ellis, M. A., and Madden, L. V. 1987. Influence of temperature and wetness duration on infection of strawberry flowers by Botrytis cinerea and disease incidence of fruit originating from infected flowers. Phytopathology 77:1225-1230.

8. Cantín, C. M., Minas, I. S., Goulas, V., Jimenez, M., Manganaris, G. A., Michailides, T. J., and Crisosto, C. H. 2012. Sulfur dioxide fumigation alone or in combination with $\mathrm{CO}_{2}$-enriched atmosphere extends the market life of highbush blueberry fruit. Postharv. Biol. Technol. 67:84-91.

9. Deytieux-Belleau, C., Geny, L., Roudet, J., Mayet, V., Doneche, B., and Fermaud, M. 2009. Grape berry skin features related to ontogenic resistance to Botrytis cinerea. Eur. Plant Pathol. 125:551-563.

10. Droby, S., and Lichter, A. 2004. Post-harvest Botrytis infection: Etiology, development and management. Pages 349-367 in: Botrytis: Biology, Pathology and Control. Y. Elad, B. Williamson, P. Tudzynski, and N. Delen, eds. Springer, Dordrecht, Netherlands.

11. Duncan, R. A., Stapleton, J. J., and Leavitt, G. M. 1995. Population dynamics of epiphytic mycoflora and occurrence of bunch rots of wine grapes as influenced by leaf removal. Plant Pathol. 44:956-965.

12. Echeverria, G., Cañumir, J., and Serri, H. 2009. Postharvest behavior of highbush blueberry fruits cv. O'Neal cultivated with different organic fertilization treatments. Chilean J. Agric. Res. 69:391-399.

13. Elmer, P. A. G., and Michailides, T. J. 2004. Epidemiology of Botrytis cinerea in orchard and vine crops. Pages 243-272 in: Botrytis: Biology, Pathology and Control. Y. Elad, B. Willianson, P. Tudzynski, and N. Delen, eds. Springer, Dordrecht, Netherlands.

14. Fourie, J. F., and Holz, G. 1998. Effects of fruit and pollen exudates on growth of Botrytis cinerea and infection of plum and nectarine fruit. Plant Dis. 82:165-170.

15. Hildebrand, P. D., McRae, K. B., and Lu, X. 2001. Factors affecting flower infection and disease severity of lowbush blueberry by Botrytis cinerea. Can. J. Plant Pathol. 23:364-370.

16. Hildebrand, P. D., Milholland, R. D., and Stretch, W. 1995. Mummy berry. Pages 11-12 in: Compendium of Blueberry and Cranberry Diseases. F. L. Caruso and D. C. Ramsdell, eds. American Phytopathological Society, St. Paul, MN.

17. Holz, G., Gütschow, M., Coertze, S., and Calitz, F. J. 2003. Occurrence of Botrytis cinerea and subsequent disease expression at different positions on leaves and bunches of grape. Plant Dis. 87:351-358.

18. Keller, M., Viret, O., and Mary Cole, F. 2003. Botrytis cinerea infection in grape flowers: Defense reaction, latency, and disease expression. Phytopathology 93:316-322.

19. Latorre, B. A., Rioja, M. E., and Lillo, C. 2001. Effect of timing on the efficacy of fungicide treatments applied against Botrytis cinerea of grapevine. Cien. Inv. Agric. 28:61-66.

20. Latorre, B. A., Rioja, M. E., and Lillo, C. 2002. Effect of temperature on flower and berry infections caused by Botrytis cinerea on table grapes. Cien. Inv. Agric. 29:145-151.

21. McClellan, W. D., and Hewitt, W. B. 1973. Early Botrytis rot of grapes: Time of infection and latency of Botrytis cinerea Pers. in Vitis vinifera L. Phytopathology 63:1151-1157.

22. Michailides, T. 1991. Susceptibility of pistachio male cultivars to Botrytis blossom and shoot blight caused by Botrytis cinerea. Plant Dis. 75:410-415.

23. Milholland, R. D. 1995. Anthracnose fruit rot (ripe rot). Pages 17-18 in: Compendium of Blueberry and Cranberry Diseases. F. L. Caruso and D. C. Ramsdell, eds. American Phytopathological Society, St. Paul, MN.

24. Milholland, R. D. 1995. Alternaria leaf spot and fruit rot. Pages 18-19 in: Compendium of Blueberry and Cranberry Diseases. F. L. Caruso and D. C. Ramsdell, eds. American Phytopathological Society, St. Paul, MN.

25. Padgett, M., and Morrison, J. 1990. Changes in grape berry exudates during fruit development and their effect on mycelial growth of Botrytis cinerea. J. Am. Soc. Hortic. Sci. 115:269-273.

26. Pezet, R., Viret, O., Perret, C., and Tabacchi, R. 2003. Latency of Botrytis cinerea Pers.: Fr. and biochemical studies during growth and ripening of two grape berry cultivars, respectively susceptible and resistant to grey mould. J. Phytopathol. 151:208-214.

27. Rivera, S. A., Zoffoli, J. P., and Latorre, B. A. 2013. Determination of optimal sulfur dioxide time and concentration product for postharvest control of gray mold of blueberry fruit. Postharv. Biol. Technol. 83:40-46.

28. Sanzani, S. M., Schena, L., De Cicco, V., and Ippolito, A. 2012. Early detection of Botrytis cinerea latent infections as a tool to improve postharvest quality of table grapes. Postharv. Biol. Technol. 68:64-71.

29. Smith, B. 1998. Botrytis blossom blight of southern blueberries: Cultivar susceptibility and effect of chemical treatments. Plant Dis. 82:924-927.

30. Smith, B., Magee, J., and Gupton, C. 1996. Susceptibility of rabiteye blueberry to postharvest diseases. Plant Dis. 80:215-218.

31. Torres, D., and Ciampi, L. 2001. Presence of B. cinerea on organic detritus of blueberry plants cv. Blue Jay, Blue Haven and Blue Ray and its relation with environmental factors. (Abstr.) XI Congr. Nacional Fitopatol., Santa Cruz, Chile.

32. Vazquez, P., Baldomá, J. A., Wright, E. R., Perez, A., and Divo de Sesar, M. 2007. First report of blueberry botrytis blight in Buenos Aires, Entre Ríos, and Córdoba, Argentina. Plant Dis. 91:639.

33. Xu, X.-M., Robinson, J. D., and Berrie, A. M. 2009. Infection of blackcurrant flowers and fruits by Botrytis cinerea in relation to weather conditions and fruit age. Crop Prot. 28:407-413. 